\title{
Effect of glass and carbon fibres on the compressive and flexural strength of the polymer concrete composite
}

\author{
Petruška, O. ${ }^{a}$, Zajac, J. ${ }^{a}$, Dupláková, D..$^{\text {a, }}$, Simkulet, V. ${ }^{a}$, Duplák, J. ${ }^{a}$, Botko, F. ${ }^{a}$ \\ ${ }^{a}$ Technical University of Košice, Faculty of Manufacturing Technologies with a seat in Prešov, Institue of Advanced \\ Technologies, Prešov, Slovak Republic
}

\section{A B S T R A C T}

This article is focused on testing the mechanical properties of polymer concrete testing samples. After a thorough literature search, the basic conditions of the research were determined and under the standards, three types of samples of special new concrete mixtures were created as a building element for special CNC machines. The samples were subjected to the research of the influence of used fillers, binders and additives on their properties. Testing was carried out in a certified laboratory and included checking the dimensions of the test bodies, weighing on the calibrated weight, determining the volumetric weight, determining the maximum load of the testing samples using special devices and then determining the compressive strength, or flexural tensile strength according to the relevant formulas. The final part of the testing also examined the morphology and mapping of the chemical composition with a focus on carbon, oxygen and aluminum using an electron microscope. The obtained results clearly show an increase in tensile and compressive strength using dispersed carbon fibre reinforcement of approximately $4 \mathrm{MPa}$. The conclusion of the article provides an overall summary of the results obtained and a summary of the features.
\end{abstract}

\section{ARTICLE INFO}

Keywords:

Concrete composite;

Polymer concrete;

Compressive strength;

Flexural strength;

Glass fibres;

Carbon fibres

*Corresponding author:

darina.duplakova@tuke.sk

(Dupláková, D.)

Article history:

Received 21 January 2019

Revised 30 November 2020

Accepted 3 December 2020

\section{References}

[1] Knapčíková, L. (2018). Surface topography of composite reinforced with fibres from used tyres, Acta Tecnología, Vol. 4, No. 2, 29-32, doi: 10.22306/atec.v4i2.36.

[2] Krolczyk, J., Legutko, S. (2014). Innovation as a key factor for entrepreneurial activity, Applied Mechanics and Materials, Vol. 657, 1046-1050, doi: 10.4028/www.scientific.net/AMM.657.1046.

[3] Neslušan, M., Turek, S., Brychta, J., Čep, R., Tabaček, M. (2007). Experimental methods in splinter machining, EDIS Žilina, Slovak Republic.

[4] Adamczak, S., Stępień, K., Wrzochal, M. (2017). Comparative study of measurement systems used to evaluate vibrations of rolling bearings, Procedia Engineering, Vol. 192, 971-975, doi: 10.1016/j.proeng.2017.06.167.

[5] Harničárová, M., Mital’ová, Z., Kušnerová, M., Valíček, J., Mital', D., Kopal, I., Václavík, V. (2016). Analysis of physical-mechanical and surface properties of wood plastic composite materials to determine the energy balance, Defect and diffusion forum, Vol. 370, 78-89, doi: 10.4028/www.scientific.net/DDF.370.78.

[6] Krolczyk, J.B., Legutko, S. (2015). Devices and equipment for mixing granular materials in industry, Applied Mechanics and Materials, Vol. 809-810, 742-747, doi: 10.4028/www.scientific.net/AMM.809-810.742.

[7] Knapcíková, L., Dupláková, D., Radchenko, S., Hatala, M. (2017). Rheological behavior modelling of composite materials used in engineering industry, TEM Journal, Vol. 6, No. 2, 242-245, doi: 10.18421/TEM62-07.

[8] Foldyna, V., Foldyna, J., Klichova, D., Klich, J., Hlaváček, P., Bodnarova, L., Jarolim, T., Mamulová Kutláková, K. (2017). Effects of continuous and pulsating water jet on CNT/concrete composite, Tehnički Vjesnik - Technical Gazette, Vol. 63, No. 10, 583-589, doi: 10.5545/sv-jme.2017.4357. 
[9] Agunsoye, J.O., Bello, S.A., Bello, L., Idehenre, M.M. (2016). Assessment of mechanical and wear properties of epoxy based hybrid composites, Advances in Production Engineering \& Management, Vol. 11, No. 1, 5-14, doi: 10.14743/apem2016.1.205.

[10] Dupláková, D., Hatala, M., Duplák, J., Radchenko, S., Steranka, J. (2018). Direct metal laser sintering - Possibility of application in production process, SAR Journal, Vol. 1, No. 4, 123-127, doi: 10.18421/SAR14-01.

[11] Trofimov, A., Mishurova, T., Lanzoni, L., Radi, E., Bruno, G., Sevostianov, I. (2018). Microstructural analysis and mechanical properties of concrete reinforced with polymer short fibers, International Journal of Engineering Science, Vol. 133, 210-218, doi: 10.1016/j.ijengsci.2018.09.009.

[12] Tanyildizi, H., Asilturk, E. (2018). Performance of phosphazene-containing polymer-strengthened concrete after exposure to high temperatures, Journal of Materials in Civil Engineering, Vol. 30, No. 12, Article ID 04018329, doi: 10.1061/(ASCE)MT.1943-5533.0002505.

[13] Jin, N.J., Yeon, J., Min, S.-H., Yeon, K.-S. (2018). Strength developments and deformation characteristics of MMAmodified vinyl ester polymer concrete, International Journal of Concrete Structures and Materials, Vol. 12, Article No. 4, doi: 10.1186/s40069-018-0232-0.

[14] Şimşek, B., Uygunoğlu, T. (2018). A full factorial-based desirability function approach to investigate optimal mixture ratio of polymer concrete, Polymer Composites, Vol. 39, No. 9, 3199-3211, doi: 10.1002/pc.24330.

[15] Hu, B., Zhang, N.-L., Liao, Y.-T., Pan, Z.-W., Liu, Y.-P., Zhou, L.-C., Liu, Z.-J., Jiang, Z.-Y. (2018). Enhanced flexural performance of epoxy polymer concrete with short natural fibers, Science China Technological Sciences, Vol. 61, No. 8, 1107-1113, doi: 10.1007/s11431-017-9272-4.

[16] Li, L., Lu, J., Fang, S., Liu, F., Li, S. (2018). Flexural study of concrete beams with basalt fibre polymer bars, Proceedings of the Institution of Civil Engineers - Structures and Buildings, Vol. 171, No. 7, 505-516, doi: 10.1680/jstbu.16.00204.

[17] Zegardło, B., Szeląg, M., Ogrodnik, P., Bombik, A. (2018). Physico-mechanical properties and microstructure of polymer concrete with recycled glass aggregate, Materials, Vol. 11, No. 7, Article No. 1213, doi: $10.3390 / \mathrm{ma11071213}$.

[18] Schmitt, A., Carvelli, V., Haffke, M.M., Pahn, M. (2018). Thermo-mechanical response of concrete sandwich panels reinforced with glass fiber reinforced polymer bars, Structural Concrete, Vol. 19, No. 3, 839-850, doi: $10.1002 /$ suco.201700048.

[19] Niaki, M.H., Fereidoon, A., Ahangari, M.G. (2018). Effect of basalt, silica sand and fly ash on the mechanical properties of quaternary polymer concretes, Bulletin of Materials Science, Vol. 41, No. 3, Article No. 69, doi: 10.1007/s12034-018-1582-6.

[20] Burlacu, A., Ciocan, V., Şerbănoiu, A.A., Barbuță, M., Verdeș, M., Cojocaru, A. (2018). Study on polymer concretes with waste of polystyrene granules, Environmental Engineering \& Management Journal, Vol. 17, No. 5, 12291235, doi: $10.30638 /$ eemj.2018.122.

[21] Niaki, M.H., Fereidoon, A., Ahangari, M.G. (2018). Experimental study on the mechanical and thermal properties of basalt fiber and nanoclay reinforced polymer concrete, Composite Structures, Vol. 191, 231-238, doi: 10.1016/i.compstruct.2018.02.063.

[22] Jafari, K., Tabatabaeian, M., Joshaghani, A., Ozbakkaloglu, T. (2018). Optimizing the mixture design of polymer concrete: An experimental investigation, Construction and Building Materials, Vol. 167, 185-196, doi: 10.1016/i.conbuildmat.2018.01.191.

[23] Niaki, M.H., Fereidoon, A., Ahangari, M.G. (2018). Mechanical properties of epoxy/basalt polymer concrete: Experimental and analytical study, Structural Concrete, Vol. 19, No. 2, 366-373, doi: 10.1002/suco.201700003.

[24] Hashemi, M.J., Jamshidi, M., Aghdam, J.H. (2018). Investigating fracture mechanics and flexural properties of unsaturated polyester polymer concrete (UP-PC), Construction and Building Materials, Vol. 163, 767-775, doi: 10.1016/i.conbuildmat.2017.12.115.

[25] Lu, Y., Zhu, T., Li, S., Liu, Z. (2018). Bond behavior of wet-bonded carbon fiber-reinforced polymer-concrete interface subjected to moisture, International Journal of Polymer Science, Vol. 2018, Article ID 3120545, doi: $10.1155 / 2018 / 3120545$.

[26] Şimşek, B., Uygunoğlu, T. (2017). A design of experiment application to improve raw materials utilization ratio of polymer concrete composites, Journal of Engineering Research, Vol. 5, No. 4., 1-18.

[27] Jafari, K., Toufigh, V. (2017). Experimental and analytical evaluation of rubberized polymer concrete, Construction and Building Materials, Vol. 155, 495-510, doi: 10.1016/j.conbuildmat.2017.08.097.

[28] Shokrieh, M.M., Rezvani, S., Mosalmani, R. (2017). Mechanical behavior of polyester polymer concrete under low strain rate loading conditions, Polymer Testing, Vol. 63, 596-604, doi: 10.1016/i.polymertesting.2017.09.015.

[29] Hwang, E.-H., Kim, Y.-Y., Song, M.-K. (2017). Durability of high performance polymer concrete composites (focusing on chemical resistance and hot water resistance), Applied Chemistry for Engineering, Vol. 28, No. 3, 360-368, doi: 10.14478/ACE.2017.1040.

[30] Yue, Q., Liu, Z., Li, R., Chen, X. (2017). Experimental investigation into the development length of carbon-fiberreinforced polymer grids in concrete, Advances in Structural Engineering, Vol. 20, No. 6, 953-962, doi: $10.1177 / 1369433216668360$.

[31] Agunsoye, J.O., Bello, S.A., Bello, L., Idehenre, M.M. (2016). Assessment of mechanical and wear properties of epoxy-based hybrid composites, Advances in Production Engineering \& Management, Vol. 11, No. 1, 5-14, doi: 10.14743/apem2016.1.205. 


\section{APEM}

\title{
Vpliv steklenih in ogljikovih vlaken na tlačno in upogibno trdnost polimerno-betonskega kompozita
}

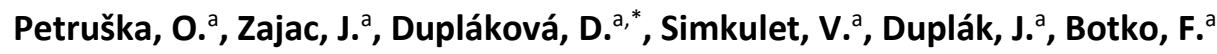 \\ ${ }^{\mathrm{a}}$ Technical University of Košice, Faculty of Manufacturing Technologies with a seat in Prešov, Institue of Advanced \\ Technologies, Prešov, Slovak Republic
}

\begin{abstract}
POVZETEK
Članek se osredotoča na preizkušanje mehanskih lastnosti vzorcev polimernega betona. Po pregledu literature so bili določeni osnovni okvirji raziskave. V skladu s standardi so bili ustvarjeni trije tipi vzorcev novih betonskih mešanic, primernih za gradbeni material za posebne CNC stroje. Raziskan je bil vpliv uporabljenih polnil, veziv in dodatkov na lastnosti vzorcev. Testiranje je bilo izvedeno $\mathrm{v}$ pooblaščenem laboratoriju in je vključevalo preverjanje dimenzij testnih vzorcev, tehtanje na kalibrirani tehtnici, določanje prostorninske teže, določanje največje obremenitve preizkusnih vzorcev s posebnimi napravami in določitev tlačne, upogibne ali natezne trdnosti v skladu $\mathrm{z}$ ustreznimi formulami. $V$ zaključnem delu testiranja je bila s pomočjo elektronskega mikroskopa proučena tudi morfologija in izvedeno je bilo kartiranje kemične sestave vzorcev s poudarkom na ogljiku, kisiku in aluminiju. Pridobljeni rezultati jasno kažejo povečanje natezne in tlačne trdnosti pri vzorcih z razpršenimi ogljikovimi vlakni za približno $4 \mathrm{MPa}$. Zaključek članka vsebuje splošen povzetek rezultatov in povzetek značilnosti materialov.
\end{abstract}

(C) 2020 CPE, University of Maribor. All rights reserved.

\section{PODATKI O ČLANKU}

Ključne besede:

Betonski kompozit;

Polimerni beton;

Tlačna trdnost;

Upogibna trdnost;

Steklena vlakna;

Ogljikova vlakna

*Kontaktna oseba:

darina.duplakova@tuke.sk

(Dupláková, D.)

Zgodovina članka:

Prejet 21. januarja 2019

Popravljen 30. novembra 2020

Sprejet 3. decembra 2020 